\title{
МЕДИЧНА МІКРОБІОЛОГІЯ, ВІРУСОЛОГІЯ ТА ІМУНОЛОГІЯ: підручник для студентів вищих медичних навчальних закладів IV рівня акредитації / За редакцією академіка НАH України В.П. Широбокова. - Вінниця: Нова Книга, 2011. - 952 с.
}
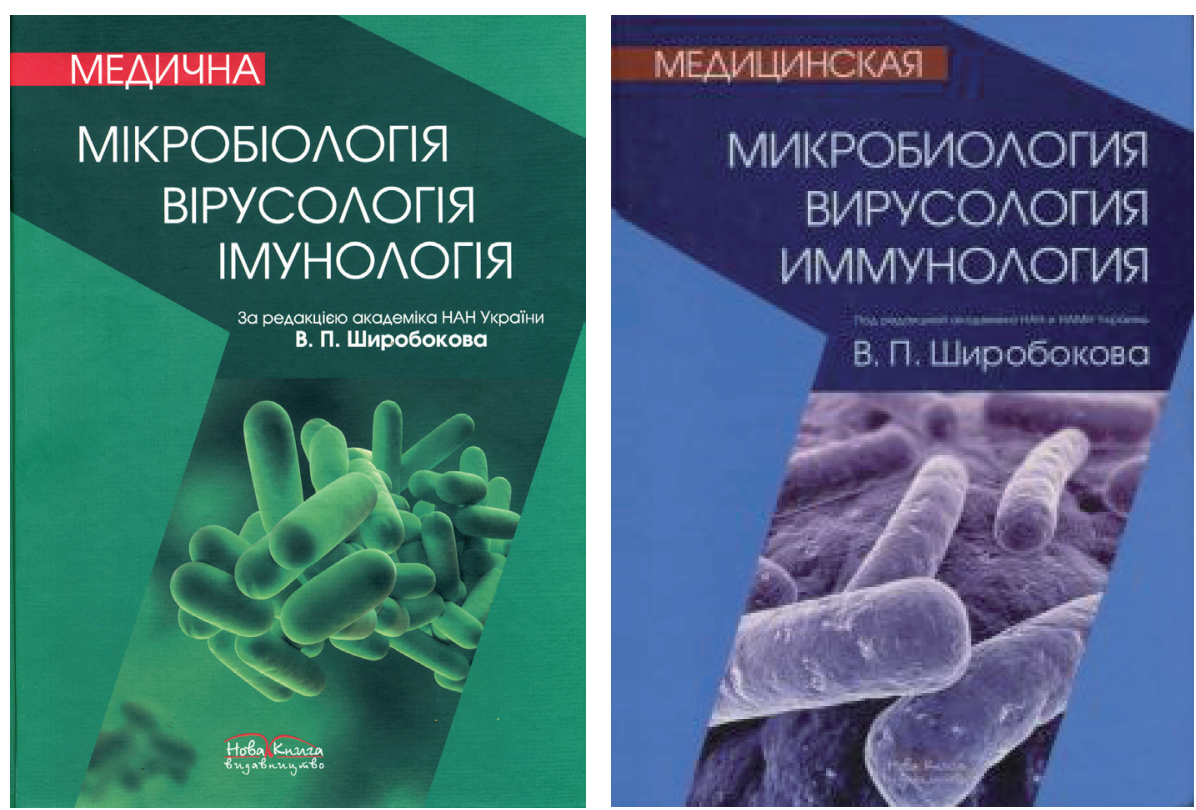

Мікроби відіграють також величезну роль в існуванні біоссрери, визначають екологічну чистоту середовища, яке оточує людину. Відповідно значення мікроорганізмів у житті людини переоцінити важко.

Базовою дисципліною, яка вивчає мікроорганізми, є мікробіологія. Однак без знань цієї дисципліни майбутньому фахівцю неможливо осягнути сучасної етіологічної структури хвороб мікробного походження, механізмів патогенного впливу інфекційних агентів на організм людини і природи тих чи інших проявів захворювання, основ епідеміології і лабораторної діагностики інфекційних хвороб, методів боротьби з ними. Тож дуже непросто підготувати підручник, який, попри величезний об'єм матеріалу, міг би

Ми живемо на Планеті мікробів, які нас оточують не тільки зовні, але й населяють зсередини. Як відомо, на одну клітину людського організму припадає від 100 до 1000 мікроорганізмів (М.Д. Ардатская, 2010). А той фракт, що в загальному геномі людини + мікроорганізми частка людських генів складає менше 1 \% (S.R. Gill et al., 2006), примушує задуматися над тим, хто в хаті господар? Якщо брати до уваги кількість структурних одиниць (клітин), обсяг наявної інформації (носієм якої є гени), швидкість оновлення популяції (у людини цей час становить близько 50 років, а у мікробів - 15-30 хвилин), то відповідь очевидна (І.В. Богадельніков і співавт., 2011).

Вважають, що понад 70 \% усіх захворювань людини мають інфекційну природу і спричиняються різноманітними патогенними мікробами. Крім того, мікробний фактор відіграє важливу роль у патогенезі багатьох так званих соматичних захворювань: злоякісних новоутворень, серцево-судинної патології, захворювань внутрішніх органів, зокрема, виразкової хвороби шлунка і дванадцятипалої кишки тощо. зацікавити студента і доступно висвітлити йому таїнства цієї науки.

У 2011 р. світ побачила капітальна праця великого колективу знаних мікробіологів, біологів, вірусологів, епідеміологів, хірургів та інших науковців за редакцією академіка НАН України, члена-кореспондента НАМН України, завідувача кафедри мікробіології, вірусології та імунології Національного медичного університету ім. О.О. Богомольця, доктора медичних наук, професора В.П. Широбокова «Медична мікробіологія, вірусологія та імунологія».

У першій частині книги «Загальна мікробіологія», яка об'єднує аж 17 розділів, відповідно до вимог навчальної програми послідовно викладено інформацію про основні методи дослідження мікроорганізмів, морфологію, структуру і класифрікацію бактерій, їх фрізіологію, вплив фрізичних, хімічних і біологічних чинників на мікроорганізми, генетику мікробів і біотехнологію, протимікробні препарати і поняття про інфекцію. 
Дуже логічними видаються насамперед наведені загальні дані про роль мікроорганізмів в існуванні біосфрери, зв'язок медичної мікробіології з іншими науками, історію розвитку мікробіології, вірусології та імунології. Пізнавальним $€$ опис мікроскопічних методів дослідження. Відрадно, що поряд з висвітленням уже класичних методів світлової, люмінесцентної та електронної мікроскопії автори не обійшли увагою надсучасні - конфокальну лазерну скануючу мікроскопію та рентґеноструктурний аналіз.

Важливим для засвоєння є викладені в окремому розділі основи систематики, класиорікації та номенклатури мікробів. Відтак описано морфологічні та фрізіологічні особливості бактерій, мікроскопічних грибів, найпростіших і вірусів. Детально висвітлено сучасні підходи до культивування бактерій і вірусів у штучних умовах, що матиме непересічне значення для освоєння методів лабораторної діагностики інфекційних захворювань, обумовлених цими групами мікроорганізмів.

Безперечно, цікавим є підрозділ, присвячений питанням етології мікроорганізмів - новому сучасному напрямку мікробіологічної науки. Тут стисло викладені оригінальні погляди на поведінку мікроорганізмів на популяційному рівні, механізми комунікативних зв'язків бактерій у популяції, поняття Quorum sensing, роль бактерійного плівкоутворення для існування цих мікроорганізмів, а також у розвитку патологічних процесів в організмі людини і підтримки епідемічних процесів.

Органічно вписується у загальну послідовність матеріалу розділ, присвячений вивченню впливу фрізичних, хімічних і біологічних фракторів на мікроорганізми. Він має важливе значення для усвідомлення принципів асептики, антисептики, дезінфрекції та стерилізації.

Враховуючи те, що бактерії і віруси є незамінним інструментом пізнання генетичних закономірностей, цілком невід'ємним у загальному опусі $€$ розділи «Генетика мікробів» і «Біотехнологія». Тут описані принципи найсучасніших молекулярно-генетичних методів діагностики: рестрикційного аналізу, методу молекулярної гібридизації, полімеразної ланцюгової реакції та риботипування, а також засади генно-інженерних біотехнологій, їх ролі у створенні засобів боротьби 3 інфекційними хворобами.

Особливу цінність для клініцистів становить характеристика сучасного арсеналу протимікробних засобів, якій присвячений окремий великий розділ. В ньому наведені основні групи хіміотерапевтичних засобів з характеристикою їх спектру протимікробної дії. Перелік основних груп сучасних антибіотиків і противірусних препаратів складено відповідно до класифрікації за механізмом дії на мікробну клітину і процеси вірогенезу.

Як відомо, хвороботворні мікроорганізми мають здатність проникати в макроорганізм і спричиняти пошкодження.
Та у людей еволюційно розвинулися різні засоби і механізми захисту. У сукупності вони звуться резистентністю організму, а фрактори резистентності укупі фрормують стан імунітету. Таким чином наука, що вивчає будову імунної системи та закономірності її фрункціонування, нерозривно пов'язана 3 мікробіологією та вірусологією. Відповідно автори дуже ретельно відпрацювали шість об'ємних розділів, присвячених загальним питанням імунології. У них на сучасному науковому рівні розкрито механізми неспецисрічного захисту організму людини. При цьому значну увагу приділено регулюванню дії імунної системи за допомогою цитокінів. Наведено сучасні дані про мембранні рецептори шаблонного розпізнавання фрагоцитів і роль окремих toll-like рецепторів у взаємодії імунокомпетентних клітин і мікробних патогенів. У підрозділі, присвяченому опису антигенів організму людини, досить повно висвітлено роль антигенів комплексу гістосумісності в розвитку захисних реакцій і антигенів кластерів диференціації у зв'язку з функцією імунокомпетентних клітин. Цієї інформації у попередніх підручниках з мікробіології та імунології не було. Стисло висвітлені основи вчення про імунну толерантність, імунопатологічні процеси, імунодефріцитні стани. В окремому розділі викладено принципи і методи імунодіагностики 3 описом не лише класичних серологічних реакцій, але й сучасних технологій - твердофразного імунофрерментного аналізу, радіоімунного аналізу, імуноблотингу тощо. Неабияк допомагають у сприйнятті матеріалу вдалі схеми та ілюстрації, які органічно вплетені у загальний текст.

Завершується перша частина книги розділом, в якому описані наріжні організаційні принципи мікробіологічної діагностики інфекційних захворювань. У ньому описано облаштування та основні вимоги до різних категорій мікробіологічних лабораторій відповідно до номенклатури ВОО3, наведено нормативні документи, які регулюють діяльність таких лабораторій у нашій країні, та правила роботи у них.

У другій частині підручника послідовно розглянуті питання спеціальної мікробіології (відомості про морфологію, фрізіологію, патогенні властивості бактерій, вірусів, мікроскопічних грибів, найпростіших і гельмінтів, сучасні методи їх діагностики, специорічної профілактики й терапії). Таким чином, автори навели достатню характеристику всіх мікроорганізмів різного рівня організації, що мають медичне значення.

Важливо, що усі назви мікроорганізмів відповідають останній класифрікації прокаріотів (Bergey's Manual of Systematic Bacteriology 2nd. Edition, 2001-2005), а також рішенням VII Міжнародного Конгресу з таксономії вірусів. У розділах, присвячених окремим збудникам, описано основні біологічні властивості, особливості екології та епідеміології біологічного виду, механізми його патогенного впливу на організм людини, необхідні для розуміння патогенезу хво- 
роби, методи лабораторної діагностики та можливості специфрічної і неспецифічної профрілактики. В окремих розділах висвітлено засади клінічної і санітарної мікробіології, розглядаються питання екології мікроорганізмів, нормальної мікрофрлори тіла людини і впливу мікроорганізмів на плід. Суттєвий інтерес для майбутніх спеціалістів становитимуть розділи, присвячені мікросрлорі ротової порожнини і мікробіологічним дослідженням у стоматології та фрармації.

У рецензованому підручнику не просто узагальнені досягнення сучасної медичної мікробіології, вірусології та імунології, але й викладені нові дані про клінічну мікробіологію та особливості імунітету при різних станах організму. Чи не найважливіше те, що автори, дотримуючись нової типової програми навчальної дисципліни «Мікробіологія, вірусологія та імунологія» з урахуванням загальноєвропейських принципів і засад, зуміли не просто об'єднати дуже різний матеріал та узагальнити літературні дані, а й зберегти власний оригінальний стиль викладання. Так, найвищої оцінки вартий розділ 31 «Замість закінчення. Мікробний літопис біосфери Землі». У цій частині наведені тісно пов'язані з мікросвітом гіпотези походження життя та еволюції біосфери, що дозволяє розширити світоглядні обрії майбутніх лікарів. Розділ вдало проілюстрований оригінальними мікрофотограсріями реліктових мікроорганізмів, виявлених у процесі авторських мікропалеонтологічних досліджень.
Особливо приємне враження справляє ілюстрування підручника. Кожен розділ містить узагальнюючий табличний матеріал, схеми описаних процесів чи високоякісні кольорові фрото, які допомагають засвоювати текстовий матеріал. Суттєво полегшує пошук необхідної інфрормації розлогий предметний покажчик, а також додатки у кінці книги.

Насамкінець слід зазначити, що цей підручник у сучасній медичній освіті України є головним джерелом одержання знань 3 дисципліни мікробіологія, вірусологія та імунологія для студентів вищих навчальних медичних закладів IV рівня акредитації, а також на усіх етапах післядипломної підготовки лікарів. Важливо, що можливість використання обговорюваного підручника не обмежена україномовними читачами. У 2015 р. з деякими виправленнями книжку було перевидано російською мовою, що дає змогу користуватися нею іноземним російськомовним студентам і лікарям.

Вважаємо, що вихід у світ рецензованого підручника став надзвичайно важливим і вчасним для забезпечення в Україні медичної освіти європейського рівня. Книга адресована передусім як підручник для студентів медичних фракультетів університетів, слухачів академій післядипломної освіти та інтернів. Вона також стане в нагоді мікробіологам і лікарям усіх спеціальностей, оскільки є сучасним довідником з мікроорганізмів і захворювань, що спричиняються ними.

Зав. кафредри інфрекційних хвороб з епідеміологією, шкірними і венеричними хворобами

ТДМУ ім. І.Я. Горбачевського, член-кор. НАМН України, профресор М.А. Андрейчин.

Отримано 17.12.2015 p 